\title{
Static Test-Based Acid Rock Drainage Formation Potential of Metalliferous Tailings from O'Kiep, South Africa
}

\author{
I.G. Erdogan ${ }^{\mathrm{a}, \mathrm{b}, \mathrm{c}}$, E. Fosso-Kankeu ${ }^{\mathrm{a}^{*}}$, S.K.O. Ntwampe ${ }^{\mathrm{b}, \mathrm{c}}$, F.B. Waanders ${ }^{\mathrm{a}}$, N. Hoth ${ }^{\mathrm{d}}$ and A. Rand $^{\mathrm{b}}$
}

\begin{abstract}
One of the environmental challenges in O'Kiep is the increased levels of potentially toxic elements (PTEs) in metalliferous tailings (MTs), which may result in acid rock drainage (ARD) through oxidation. In this study, laboratory-based static tests were conducted on MTs to predict the risk of acid rock drainage potential (ARDP). Mineralogical analysis of the MTs showed that the MTs consisted mainly of quartz, microline, muscovite, albite, anorthite, magnetite, magnesioferrite, gypsum and halloysite-10A. The major oxides, i.e. $\mathrm{SiO}_{2}>\mathrm{Al}_{2} \mathrm{O}_{3}>\mathrm{Fe}_{2} \mathrm{O}_{3}>\mathrm{CaO}>\mathrm{MgO}>\mathrm{K}_{2} \mathrm{O}>\mathrm{Na}_{2} \mathrm{O}>\mathrm{TiO}_{2}>\mathrm{P}_{2} \mathrm{O}_{5}>$ $\mathrm{SO}_{3}>\mathrm{Cr}_{2} \mathrm{O}_{3}>\mathrm{MnO}>\mathrm{NiO}$, in the MTs were higher; while the concentrations of PTEs were in the following sequence: $\mathrm{F}>\mathrm{Cu}>\mathrm{Cr}>$ $\mathrm{Mn}>\mathrm{S}>\mathrm{Zr}>\mathrm{Ba}>\mathrm{Sr}>\mathrm{V}>\mathrm{Cl}>\mathrm{Rb}>\mathrm{Ni}>\mathrm{Zn}>\mathrm{Y}>\mathrm{Co}$. The mineralogical and geochemical characteristics of the MTs indicated oxidative weathering of the PTEs. The MTs paste averaged a $\mathrm{pH}$ of 3.1 , with the net neutralization potential of $-210 \mathrm{~kg} \mathrm{CaCO}_{3} / \mathrm{t}$, neutralizing potential ratio of 0.1 and a total sulfur of $6.1 \%$, an indication that the MTs would be prone to ARDP. Furthermore, the leaching of the MTs increases the risk of contamination of surrounding groundwater bodies in O'Kiep. Additionally, there are increasing concerns over significant potential environmental health effects of the MTs, including the mobility of the PTEs, which necessitates the development of suitable strategies for reclamation and the rehabilitation of the mining site in the O'Kiep area.
\end{abstract}

Keywords - Acid rock drainage potential, metalliferous tailings, O'Kiep, potentially toxic elements, static tests.

\section{INTRODUCTION}

Metalliferous mining operations generate large volumes of finely crushed rock, commonly referred to as metalliferous tailings (MTs). It is characterized by fine particle size $(>100 \mu \mathrm{m})$ and is stored in the tailings storage facilities (TSFs') [1]. MTs, especially those found in arid or semiarid

Manuscript received October 11, 2019. The authors appreciate the sponsorship from North-West University, Cape Peninsula University of Technology and the National Research Foundation of South Africa.

${ }^{a}$ Water Pollution Monitoring and Remediation Initiatives Research Group in the CoE C-based fuels School of Chemical and Minerals Engineering, Faculty of Engineering, North-West University, Potchefstroom - South Africa.

${ }^{\mathrm{b}}$ Bioresource Engineering Research Group (BioERG), Department of Biotechnology, Cape Peninsula University of Technology, Cape Town, South Africa.

${ }^{c}$ Department of Chemical Engineering, Cape Peninsula University of Technology, Cape Town South Africa.

${ }^{\mathrm{d}}$ Institute of Mining and Special Civil Engineering, Technische Universität Bergakademie Freiberg, Saxony, Germany. environments, pose a long-term health hazard for nearby communities through exposure to potentially toxic elements (PTEs) containing dust originating from the MTs with observed minimal plant growth due to soil toxicity [2]. The reactivity of MTs can result in acidic, highly charged waters [3]. Disposal of MTs is a major concern for many countries as it contaminates the environment including the atmosphere, water resources and soil $[4,5]$. The MTs always contain PTEs concentrated during ore processing, which may disperse into the nearby environment and threaten public health [6]. Elements such as $\mathrm{Al}, \mathrm{Cd}, \mathrm{Cu}, \mathrm{Fe}$, $\mathrm{Mn}, \mathrm{Pb}$ and $\mathrm{Zn}, \mathrm{Mn}$ are essential for cell growth and metabolism; however, at high levels, they are toxic for living organisms [5]; hence, referred to as PTEs. Under watery acidic conditions, these PTEs will be released from MTs [7], as they will undergo chemical alteration under such conditions. The chemical alterations are most often a function of exposure to atmospheric oxidation[8].

TSF containing copper sulfide MTs in O'Kiep has been exposed to the weathering reactions for years. Although the environmental impact of MTs on the nearby environments, including windblown is well known [9], only a few comprehensive studies have been carried out in O'Kiep. In general, the primary minerals in the MTs are quartz and pyrite, with secondary minerals such as goethite. Acid rock drainage (ARD) from such MTs is generated by the moisture-based weathering and oxidation of sulfide minerals such as pyrite [10]. ARD management approach is neutralization by an alkaline reagent such as limestone to raise the $\mathrm{pH}$ and remove most of the PTEs through precipitation reactions $[10,11]$. O'Kiep MTs are potentially primary contributors to ARD due to their high sulfide content [12]. Generally, studies on acid rock drainage formation potential (ARDP) of the MTs in O'Kiep are limited. ARD prediction is a significant subject in order to predict and prevent long-term deleterious environmental contamination. However, the extent of the acid generation, as well as the sources and dynamics of PTEs from O'Kieps MTs, have not been determined thus far. Therefore, the geochemical and mineralogical characterization of these MTs was carried out in order to evaluate the capacity for PTEs release over time. In addition, static tests such as acid-base accounting (ABA) were conducted in order to determine the O'Kieps MTs acid generating potential. 


\section{MATERIALS AND METHODS}

\section{A. Study area and sample collection}

The MTs used for this study were collected from a tailings storage facility (TSF) in the arid town of O'Kiep [29 $35^{\prime} 45.0^{\prime \prime} \mathrm{S}$ $\left.17^{\circ} 52^{\prime} 51.0^{\prime \prime} \mathrm{E}\right]$. The main climatic and geological characteristics of the study area have been described by Erdogan [13] . Approximately $5 \mathrm{~kg}$ of MTs representative of grab samples $(n=10)$ using generic field sampling guidelines described by USEPA Operating Protocol for Soil sampling USEPA [14] and Moyle and Causey [15]. Each sample was collected at a depth of $0.6 \mathrm{~m}$ from the surface, using a Draper 24414 steel auger [16], during August 2017 (wet season). The sampling points were marked (MT1 to MT10) using a Global Positioning System (GPS), as shown in Fig.1.
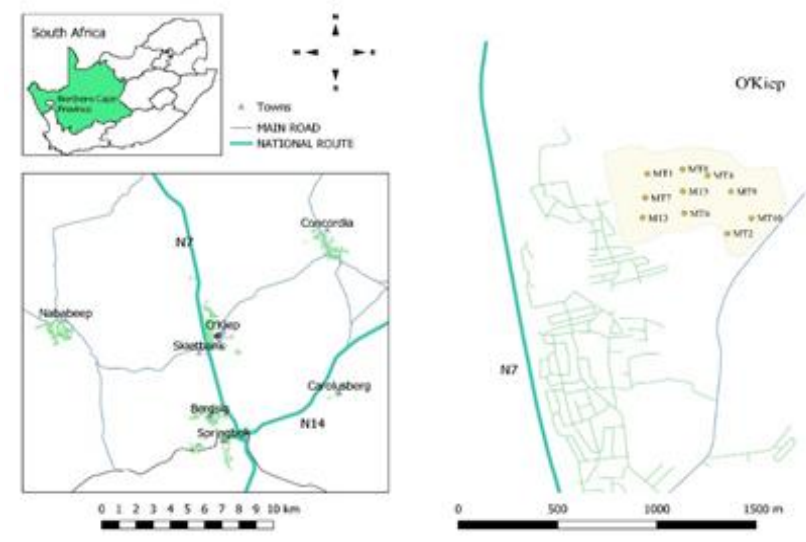

Fig. 1: Sampling points generated using Quantum GIS software (v. 2.18.11) and data from National Geo-Spatial Information (NGI).

The samples were air-dried and were homogenized and sieved to $2 \mathrm{~mm}$ in the laboratory. All samples $(\mathrm{n}=10)$ were heterogeneously mixed to form one composite sample of approximately $5 \mathrm{~kg}$. The composite sample was stored in double-sealed plastic zipper bags and further analyses were conducted. A portion of the MTs sample was used for mineralogical and geochemical characterization and was analyzed at the University of Cape Town, Department of Geological Sciences, South Africa. The mineral phases present in the MTs samples were identified and quantified using the Philips PW1130/90 X-ray diffractometer (XRD), and the geochemical composition oxides and potentially toxic elements (PTEs) of the MTs sample were measured by Panalytical Axios wavelength-dispersive X-ray fluorescence (XRF). The details of sample preparation, instrumentation condition for each method are described by Beckhoff [17] and Compton [18].

\section{B. Static tests}

A modified field and laboratory test method for ABA Sobek [19] and test modified by Lawrence and Wang [20] was used in static tests. Additionally, a prediction test was performed using a paste for $\mathrm{pH}$ testing to assess individual samples' acid-forming characteristics. Static tests are empirical techniques usually conducted to predict ARDP. The most common static tests ABA [21], which is based on the determination of three main factors: 1] acid consumption 2] acid formation and 3] determination of the net acid consumption or production [22]. Subsequently, the determination of acid potential (AP) and neutralization potential (NP) allowed for the computation of the net neutralization potential (NNP), including the net potential neutralizing ratio (NPR) - a criteria used for the determination of ARDP of the MTs sample.

\section{RESULTS}

\section{A. Mineralogy and geochemical characterization}

The primary minerals in the MTs were quartz, microcline, albite, magnesioferrite, magnetite, gypsum, clinochlore-1MIIb, anorthite, Muscovite-1M and halloysite-10A as presented in Table I. These were interlinked to the geochemical conditions at the surface of the TSF, which revealed a heterogenic environment that can be categorized divided into an acidic and oxidizing zone. The major oxides and PTEs are presented in Table II.

TABLE I: MINERALOGY OF THE METALLIFEROUS TAILINGS FROM O'KIEP

\begin{tabular}{l|c|c}
\hline \hline Minerals & Formula & $\%$ \\
\hline Quartz & $\mathrm{SiO}_{2}$ & 26.3 \\
Microcline & $\mathrm{KAlSi}_{3} \mathrm{O}_{8}$ & 10.4 \\
Albite & $\mathrm{NaAlSi}_{3} \mathrm{O}_{8}$ & 8.34 \\
Magnesioferrite & $\mathrm{MgFe}_{2} \mathrm{O}$ & 4.17 \\
Magnetite & $\mathrm{Fe}_{2} \mathrm{O}_{4}$ & 4.17 \\
Gypsum & $\mathrm{CaSO}_{4} \cdot 2 \mathrm{H}_{2} \mathrm{O}$ & 2.6 \\
Clinochlore-1MIlb & $\left(\mathrm{Mg}_{5} \mathrm{Al}\right)\left(\mathrm{Si}_{,} \mathrm{Al}_{4} \mathrm{O}_{10}(\mathrm{OH})_{8}\right.$ & 1.13 \\
Anorthite & $\left(\mathrm{Ca}_{2} \mathrm{Na}_{2}\left(\mathrm{Al}, \mathrm{Si}_{2}\right)_{2} \mathrm{Si}_{2} \mathrm{O}_{8}\right.$ & 0.65 \\
Muscovite-1M & $\mathrm{KAl}_{2} \mathrm{Si}_{3} \mathrm{AlO}{ }_{10}(\mathrm{OH})_{2}$ & 0.33 \\
Halloysite-10A & $\mathrm{Al}_{2} \mathrm{Si}_{2} \mathrm{O}_{5}(\mathrm{OH})_{4} \cdot 2 \mathrm{H}_{2}$ & 0.26 \\
\hline \hline
\end{tabular}

TABLE II: OXIDES AND POTENTIALLY TOXIC ELEMENTS FROM METALLIFEROUS TAILINGS

\begin{tabular}{|c|c|c|c|}
\hline Oxides & wt. $\%$ & PTEs) & $\mathrm{mg} / \mathrm{kg}$ \\
\hline $\mathrm{SiO}_{2}$ & 57.4 & $\mathrm{~F}$ & 1177 \\
\hline $\mathrm{Al}_{2} \mathrm{O}_{3}$ & 13.5 & $\mathrm{Cu}$ & 921 \\
\hline $\mathrm{Fe}_{2} \mathrm{O}_{3}$ & 12.5 & $\mathrm{Cr}$ & 877 \\
\hline $\mathrm{CaO}$ & 3.41 & Mn & 830 \\
\hline $\mathrm{MgO}$ & 2.57 & $\mathrm{~S}$ & 786 \\
\hline $\mathrm{K}_{2} \mathrm{O}$ & 2.56 & $\mathrm{Zr}$ & 753 \\
\hline $\mathrm{Na}_{2} \mathrm{O}$ & 2.49 & $\mathrm{Ba}$ & 686 \\
\hline $\mathrm{TiO}_{2}$ & 1.56 & $\mathrm{Sr}$ & 249 \\
\hline $\mathrm{P}_{2} \mathrm{O}_{5}$ & 0.48 & V & 247 \\
\hline $\mathrm{SO}_{3}$ & 0.27 & $\mathrm{Cl}$ & 168 \\
\hline $\mathrm{Cr}_{2} \mathrm{O}_{3}$ & 0.12 & $\mathrm{Rb}$ & 158 \\
\hline $\mathrm{MnO}$ & 0.11 & $\mathrm{Ni}$ & 114 \\
\hline $\mathrm{NiO}$ & 0.02 & $\mathrm{Zn}$ & 98.0 \\
\hline LOL & 1.92 & $\mathrm{Y}$ & 86.9 \\
\hline Total & 99.4 & $\mathrm{Co}$ & 37.5 \\
\hline
\end{tabular}

\section{A. Static test predictions}

Static tests were carried out in the MTs to measure the acidic and neutralization potentials of the sampled MTs [19]. The paste $\mathrm{pH}$ test was also used to indicate the nature of the studied MTs in terms of $\mathrm{pH}[23]$. The ABA static test was conducted to predict the acid-generating potential of the MTs. ABA measurements indicate $\mathrm{AP}$ and $\mathrm{NP}$ of a given sample. The ABA results according to the modified static test proposed by Sobek 
[19] and Lawrence, and Wang [20] are shown in Table III.

TABLE III: ACID-BASE ACCOUNTING ANALYSES OF METALLIFEROUS TAILINGS FROM O'KIEP

$$
\text { Paste } \mathrm{pH}
$$

Total Sulphur (\%)

Acid Potential (AP) (kg/t)

Neutralization Potential (NP)

Nett Neutralization Potential (NNP)

Neutralising Potential Ratio (NPR)

\section{B. Static tests predictions}

Static tests (Table II) were conducted in order to define the potential acidity generated by the MTs disposed-off in TSF in OKiep. The MTs samples used in this study were collected in acidic zones of the TSF which was confirmed by the paste $\mathrm{pH}$ (3.1) of the MTs, revealing the elevated acidity of the MTs. Low paste $\mathrm{pH}$ can be related to iron sulfide oxidation and also to soluble mineral dissolution [32]. The modified ABA test classified the MTs sample as having low sulphide-S content $(6.1 \%)$ and highly negative values of NNP $\left(-210 \mathrm{~kg} \mathrm{CaCO}_{3} / \mathrm{t}\right)$ indication that the MTs are likely to generate ARD when exposed to atmospheric conditions [33].

Additionally, based on the NPR ratio of 0.1 and a total sulfur content (S) of $>3 \%$, there can be a higher chance of ARDP [34]. The value of the NP obtained was -19 in MTs studied which is in accordance with the low values of acid-neutralizing minerals obtained, such as $\mathrm{CaO}(3.41 \mathrm{mg} / \mathrm{kg}$ ) and gypsum (2.6 wt\%); albeit, these conditions could enhance PTEs leachability and cause an increased environmental risk for the nearby groundwater sources. ARD seepage effects can manifest in low $\mathrm{pH}$ waters (1.4 to 4 ), with subsequent precipitates of hydrous ferric oxides including efflorescent sulfate salts, and blooms of green filamentous biofilms on the TSF [35] which is the case in O'Kiep. Consequently, the effects of ARD and aggradation by mineralized MTs would affect many communities further downstream [36], therefore reducing the amount of usable water in a country where physical water scarcity is already a concern [37-55]. Additionally, the chemical and physical dispersion of PTEs might continue from the TSF for the predictable future unless a mitigation strategy is implemented.

\section{CONCLUSION}

The MTs of O'Kiep contains PTEs such as $\mathrm{F}>\mathrm{Cu}>\mathrm{Cr}>\mathrm{Mn}$ $>\mathrm{S}>\mathrm{Zr}>\mathrm{Ba}>\mathrm{Sr}>\mathrm{V}>\mathrm{Cl}>\mathrm{Rb}>\mathrm{Ni}>\mathrm{Zn}>\mathrm{Y}>\mathrm{Co}$. While the, major oxides were found to be $\mathrm{SiO}_{2}>\mathrm{Al}_{2} \mathrm{O}_{3}>\mathrm{Fe}_{2} \mathrm{O}_{3}>\mathrm{CaO}>$ $\mathrm{MgO}>\mathrm{K}_{2} \mathrm{O}>\mathrm{Na}_{2} \mathrm{O}>\mathrm{TiO}_{2}>\mathrm{P}_{2} \mathrm{O}_{5}>\mathrm{SO}_{3}>\mathrm{Cr}_{2} \mathrm{O}_{3}>\mathrm{MnO}>$ $\mathrm{NiO}$. The NNP values of the tailings were $-210 \mathrm{~kg} \mathrm{CaCO}_{3} / \mathrm{t}$, and sulfur content was high $(6.1 \%)$, hence, the MTs were classified as acid-producing by the ABA test. Although the tailings were disposed years ago, the MTs are likely to produce ARD containing PTEs for a long period unless remedial measures are taken into consideration. It is recommended that a kinetic test be designed to mimic weathering at the laboratory scale to determine the rate of acid-generation, the variation over time in leachate water quality and thus allow to develop mitigating strategies.

\section{ACKNOWLEDGMENT}

Acknowledgments: The authors are grateful to the sponsor from the National Research Foundation (NRF) in South Africa (Thuthuka Grant No.: TTK180409318662).

\section{REFERENCES}

[1] P. Perumal, K. Piekkari, H. Sreenivasan, P. Kinnunen, and M. Illikainen, "One-part geopolymers from mining residues-Effect of thermal treatment on three different tailings," Minerals Engineering, vol. 144, p. 106026, 2019. 
https://doi.org/10.1016/j.mineng.2019.106026

[2] L. E. De-Bashan, J.-P. Hernandez, K. N. Nelson, Y. Bashan, and R. M. Maier, "Growth of quailbush in acidic, metalliferous desert mine tailings: effect of Azospirillum brasilense Sp6 on biomass production and rhizosphere community structure," Microbial Ecology, vol. 60, no. 4, pp. 915-927, 2010. https://doi.org/10.1007/s00248-010-9713-7

[3] A. Elghali, M. Benzaazoua, B. Bussière, and T. Genty, "Spatial mapping of acidity and geochemical properties of oxidized tailings within the former Fagle/Telbel mine site," Minerals, vol. 9, no. 3, p. 180, 2019. https://doi.org/10.3390/min9030180

[4] S.K., Behera, D.P., Mishra, C.N., Ghosh, P.K., Mandal, K.M.P., Singh, J. Buragohain, and P.K., Singh, "Characterization of lead-zinc mill tailings, fly ash and their mixtures for paste backfilling in underground metalliferous mines," Environmental Earth Sciences, vol. 78, no. 14, p. 394, July 102019 https://doi.org/10.1007/s12665-019-8395-9

[5] G. R. Rout, D. Swain, and B. Deo, "Restoration of metalliferous mine waste through genetically modified crops," in Transgenic Plant Technology for Remediation of Toxic Metals and Metalloids: Elsevier, 2019, pp. 257-278.

https://doi.org/10.1016/B978-0-12-814389-6.00012-2

[6] L. Hu, H. Wu, L. Zhang, P. Zhang, and Q. Wen, "Geotechnical properties of mine tailings," Journal of Materials in Civil Engineering, vol. 29, no. 2, p. 04016220,2016 https://doi.org/10.1061/(ASCE)MT.1943-5533.0001736

[7] J.L. Liu, J., Yao, F., Wang, N., Min, J.H., Gu, Z.F., Li, G., Sunahara, R., Duran, T., Solevic-Knudsen, K.A., Hudson-Edwards, and L. Alakangas, "Bacterial diversity in typical abandoned multi-contaminated nonferrous metal (loid) tailings during natural attenuation," Environmental Pollution, vol. 247, pp. 98-107, 2019. https://doi.org/10.1016/j.envpol.2018.12.045

[8] D. Kossoff, W. Dubbin, M. Alfredsson, S. Edwards, M. Macklin, and K. A. Hudson-Edwards, "Mine tailings dams: characteristics, failure, environmental impacts, and remediation," Applied Geochemistry, vol. 51, pp. 229-245, 2014 https://doi.org/10.1016/j.apgeochem.2014.09.010

[9] A. Rozendaal, T. Rudnick, and R. Heyn, "Mesoproterozoic base metal sulphide deposits in the Namaqua Sector of the Namaqua-Natal Metamorphic Province, South Africa: a review," South African Journal of Geology 2017, vol. 120, no. 1, pp. 153-186, 2017. https://doi.org/10.25131/gssajg.120.1.153

[10] K. Khoeurn, A. Sasaki, S. Tomiyama, and T. Igarashi, "Distribution of zinc, copper, and iron in the tailings dam of an abandoned mine in Shimokawa, Hokkaido, Japan," Mine Water and the Environment, vol. 38, no. 1, pp. 119-129, March 01 2019. Available: https://link.springer.com/article/10.1007/s10230-018-0566-5 https://doi.org/10.1007/s10230-018-0566-5

[11] S. Heviankova, I. Bestova, M. Kyncl, L. Simková, and M. Zechner, "Calcium carbonate as an agent in acid mine water neutralization," Inżynieria Mineralna, vol. 14, 2013

[12] M. Amponsah-Dacosta and D. L. Reid, "Mineralogical characterization of selected South African mine tailings for the purpose of mineral carbonation," An Interdisciplinary Response to Mine Water Challenges; Sui, W., Sun, Y., Wang, C., Eds, pp. 686-692, 2014.

[13] I. G. Erdogan, E. Fosso-Kankeu, S. K. O. Ntwampe, F. B. Waanders, N. Hoth, and A. Randb, "Potential toxic elements contamination of soils in O'Kiep, an arid region of Namaqualand, South Africa " presented at the 10th Int'l Conference on Advances in Science, Engineering, Technology \& Healthcare (ASETH-18) Nov. 19-20, 2018 Cape Town (South Africa), 2018.

[14] USEPA. Operating protocol for soil sampling, 2014. Available: https://www.epa.gov/quality/soil-sampling

[15] P. R. Moyle and J. D. Causey, "Chemical composition of samples collected from waste rock dumps and other mining-related features at selected phosphate mines in southeastern Idaho, western Wyoming, and northern Utah," US Geological Survey 2331-1258, 2001. https://doi.org/10.3133/ofr01411

[16] P. Schoeneberger, D. Wysocki, and E. Benham, "Soil Survey Staff: Field book for describing and sampling soils, Version 3.0," Natural Resources Conservation Service, National Soil Survey Center: Lincoln, NE, USA, 2012
[17] B. Beckhoff, B. Kanngießer, N. Langhoff, R. Wedell, and H. Wolff, Handbook of practical X-ray fluorescence analysis. Springer Science \& Business Media, 2007. https://doi.org/10.1007/978-3-540-36722-2

[18] J. S. Compton, R. A. White, and M. Smith, "Rare earth element behavior in soils and salt pan sediments of a semi-arid granitic terrain in the Western Cape, South Africa," Chemical Geology, vol. 201, no. 3-4, pp. 239-255, 2003 https://doi.org/10.1016/S0009-2541(03)00239-0

[19] A. A. Sobek, Field and laboratory methods applicable to overburdens and minesoils. Ohio: Industrial Environmental Research Laboratory: United States Environmental Protection Agency, 1978.

[20] R. Lawrence and Y. Wang, "Determination of neutralization potential for acid rock drainage prediction," MEND project, vol. 1, no. 3, p. 38, 1996.

[21] K. Ferguson and P. Erickson, "Pre-mine prediction of acid mine drainage," in Environmental Management of Solid Waste: Springer, 1988, pp. 24-43. https://doi.org/10.1007/978-3-642-61362-3_2

[22] B. Lottermoser, "Mine Wastes: Characterization, treatment and environmental impacts. Mine Wastes: Characterization, Treatment and Environmental Impacts," ed, 2010.

[23] K. Lapakko, "Metal mine rock and waste characterization tools: an overview," Mining, Minerals and Sustainable Development, vol. 67, pp. $1-30,2002$

[24] J. Zheng, Y. Zhu, and Z. Zhao, "Utilization of limestone powder and water-reducing admixture in cemented paste backfill of coarse copper mine tailings," Construction and Building Materials, vol. 124, pp. 31-36, 2016. https://doi.org/10.1016/j.conbuildmat.2016.07.055

[25] J. Potgieter, "Exploration in the Okiep Copper District, Northern Cape Province, South Africa: An overview," South African Journal of Geology, vol. 99, no. 2, pp. 209-220, 1996.

[26] Y. Moon, Y. Song, and H.-S. Moon, "The potential acid-producing capacity and factors controlling oxidation tailings in the Guryong mine, Korea," Environmental Geology, vol. 53, no. 8, pp. 1787-1797, February 012008. https://doi.org/10.1007/s00254-007-0784-9

[27] Y. Liu and L. Huang, "Magnetite recovery from copper tailings increases arsenic distribution in solution phase and uptake in native grass," Journal of Environmental Management, vol. 186, pp. 175-182, 2017. https://doi.org/10.1016/j.jenvman.2016.05.025

[28] L. Rudzani, J. R. Gumbo, B. Yibas, and O. Novhe, "Acid Base Accounting (ABA) of mine tailings for the Potential of Acid Mine Drainage in the Sabie-Pilgrim's Rest Goldfields, South Africa," presented at the South Africa, 2018. Available: https://www.imwa.info/docs/imwa_2018/IMWA2018_Lusunzi_392.pdf

[29] I. G. Erdogan, E. Fosso-Kankeu, S. K. Ntwampe, F. B. Waanders, N. Hoth, and A. Rand, "Acid rock drainage prediction of metalliferous soils from O'Kiep, Namaqualand, South Africa: A Humidity Cell Test assessment," $2019 . \quad$ Available: https://www.imwa.info/docs/imwa_2019/IMWA2019_Erdogan_613.pdf

[30] Karlsson, T., Räisänen, M.L., Lehtonen, M. and Alakangas, L., Comparison of static and mineralogical ARD prediction methods in the Nordic environment. Environmental Monitoring and Assessment, vol. 190, no. 12, pp.719, 2018. https://doi.org/10.1007/s10661-018-7096-2

[31] K. Ziegler, J. C. Hsieh, O. A. Chadwick, E. F. Kelly, D. M. Hendricks, and S. M. Savin, "Halloysite as a kinetically controlled end product of arid-zone basalt weathering," Chemical Geology, vol. 202, no. 3-4, pp. $461-478,2003$ https://doi.org/10.1016/j.chemgeo.2002.06.001

[32] D. S. Yucel and A. Baba, "Prediction of acid mine drainage generation potential of various lithologies using static tests: Etili coal mine (NW Turkey) as a case study," Environmental Monitoring and Assessment, vol. 188 , no. 8 , p. $473,2016$. https://doi.org/10.1007/s10661-016-5462-5

[33] N. E. Nieva, L. Borgnino, and M. G. García, "Long term metal release and acid generation in abandoned mine wastes containing metal-sulphides," Environmental Pollution, vol. 242, pp. 264-276, 2018 https://doi.org/10.1016/j.envpol.2018.06.067 
[34] R. Cruz, V. Bertrand, M. Monroy, and I. González, "Effect of sulfide impurities on the reactivity of pyrite and pyritic concentrates: a multi-tool approach," Applied Geochemistry, vol. 16, no. 7-8, pp. 803-819, 2001. https://doi.org/10.1016/S0883-2927(00)00054-8

[35] M. Wierzbicka-Wieczorek, B. G. Lottermoser, S. Kiefer, S. Sindern, L. Gronen, and A.-S. Hensler, "Indium distribution in metalliferous mine wastes of the Iberian Pyrite Belt, Spain-Portugal," Environmental Earth Sciences, vol. 78, no. 8, p. 253, April 102019. https://doi.org/10.1007/s12665-019-8263-7

[36] P. Cruz-Hernández, R. Pérez-López, A. Parviainen, M. B. Lindsay, and J. M. Nieto, "Trace element-mineral associations in modern and ancient iron terraces in acid drainage environments," Catena, vol. 147, pp. 386-393, 2016 https://doi.org/10.1016/j.catena.2016.07.049

[37] Elvis Fosso-Kankeu. 2019. Nano and Bio-based Technologies for wastewater treatment: Prediction and Control Tools for the dispersion of Pollutants in the Environment. Wiley Scrivener. ISBN: 978-1-119-57709-6. Pp 301-336.

[38] Elvis Fosso-Kankeu. 2019. New Horizons in Wastewaters Management: Emerging Monitoring and Remediation Strategies. Nova Science Publishers. ISBN: 978-1-53615-659-1.

[39] J.G. Redelinghuys, E. Fosso-Kankeu, G. Gericke, F. Waanders. 2019. Coal Power Plant Wastewater Treatment by Thermal and Membrane Technologies. In Nano and Bio-based Technologies for wastewater treatment: Prediction and Control Tools for the dispersion of Pollutants in the Environment. Editor: Elvis Fosso-Kankeu. Wiley Scrivener. ISBN: 978-1-119-57709-6. Pp 149-168. https://doi.org/10.1002/9781119577119.ch5

[40] N. Mukwevho, E. Fosso-Kankeu, F. Waanders. 2019. PAHs Released from Coal Tars and Potential Removal Using Nanocatalysts. In Nano and Bio-based Technologies for wastewater treatment: Prediction and Control Tools for the dispersion of Pollutants in the Environment. Editor: Elvis Fosso-Kankeu. Wiley Scrivener. ISBN: 978-1-119-57709-6. Pp 169-203. https://doi.org/10.1002/9781119577119.ch6

[41] E. Fosso-Kankeu, P. Jagals, H. Du Preez, Exposure of rural households to toxic cyanobacteria in container-stored water. Water SA, Vol. 34, no. 5, pp. 631-636, 2008. https://doi.org/10.4314/wsa.v34i5.180660

[42] E. Fosso-Kankeu, A. Mulaba-Bafubiandi, B.B. Mamba, T.G. Barnard, Mitigation of $\mathrm{Ca}, \mathrm{Fe}$, and $\mathrm{Mg}$ loads in surface waters around mining areas using indigenous microorganism strains. Journal of Physics and Chemistry of the Earth, Vol. 34, pp. 825-829, 2009. https://doi.org/10.1016/j.pce.2009.07.005

[43] E. Fosso-Kankeu, H. Du Preez, P. Jagals, The health implication of relationships between bacterial endotoxin, cyanobacteria, coliforms and water stored in domestic containers of rural households in South Africa. Journal of Water and Health, Vol. 8, no. 4, pp. 601-610, 2010. https://doi.org/10.2166/wh.2010.094

[44] E. Fosso-Kankeu, A. Mulaba-Bafubiandi, B.B. Mamba, L. Marjanovic, T.G. Barnard, A comprehensive study of physical and physiological parameters that affect biosorption of metal pollutants from aqueous solutions. Journal of Physics and Chemistry of the Earth, Vol. 35, pp. 672-678, 2010 https://doi.org/10.1016/j.pce.2010.07.008

[45] E. Fosso-Kankeu, A.F. Mulaba-Bafubiandi, B.B. Mamba and T.G. Barnard, Prediction of metal-adsorption behaviour in the remediation of water contamination using indigenous microorganisms. Journal of Environmental Management. Vol. 92, no. 10, pp. 2786-2793, 2011. https://doi.org/10.1016/j.jenvman.2011.06.025

[46] H. Mittal, E. Fosso-Kankeu, Shivani B. Mishra, Ajay K. Mishra, Biosorption potential of Gum ghatti-g-poly (acrylic acid) and susceptibility to biodegradation by B. subtilis. International Journal of Biological Macromolecules. Vol. 62, pp. 370-378, 2013. https://doi.org/10.1016/j.ijbiomac.2013.09.023

[47] E. Fosso-Kankeu, F. Waanders, E. Maloy, Copolymerization of ethyl acrylate onto guar gum for the adsorption of $\mathrm{Mg}$ (II) and $\mathrm{Ca}$ (II) ions. Desalination and Water Treatment. doi: 10.1080/19443994.2016.1165147: pp. 1-10, 2016.

[48] E. Fosso-Kankeu, F. Waanders, C.L. Fourie, Adsorption of Congo Red by surfactant-impregnated bentonite clay. Desalination and Water Treatment. doi: 10.1080/19443994.2016.1177599: pp. 1-9, 2016
[49] A. Manyatshe, E. Fosso-Kankeu, D. van der Berg, N. Lemmer, F. Waanders, H. Tutu, Metal retention potential of sediment and water quality in the Mooi River, South Africa. Desalination and Water Treatment. doi: 10.5004/dwt2017.20222. 2017.

[50] E. Fosso-Kankeu, A. Manyatshe, F. Waanders, Mobility potential of metals in acid mine drainage occurring in the Highveld area of Mpumalanga Province in South Africa: Implication of sediments and efflorescent crusts. International Biodeterioration and Biodegradation. Vol. 119, pp. 661-670, 2017. https://doi.org/10.1016/j.ibiod.2016.09.018

[51] E. Fosso-Kankeu, H. Mittal, F. Waanders, S.S. Ray, Thermodynamic properties and adsorption behaviour of hydrogel nanocomposites for cadmium removal from mine effluents. Journal of Industrial and Engineering Chemistry. Vol. 48, pp. 151-161, 2017. https://doi.org/10.1016/j.jiec.2016.12.033

[52] A. Manyatshe, E. Fosso-Kankeu, D. van der Berg, N. Lemmer, F. Waanders, H. Tutu, Dispersion of inorganic contaminants in surface water in the vicinity of Potchefstroom. Physics and Chemistry of the Earth. Vol. 100, pp. 86-93, 2017. https://doi.org/10.1016/j.pce.2017.04.008

[53] Erdogan IC, Fosso-Kankeu E, Ntwampe SKO, Waanders FB, Hoth N, Rand A, Farrar TJ. 2019. Households water quality in O'kiep - South Africa and community perception of related health risks. 167(2019): 145-155. https://doi.org/10.5004/dwt.2019.24576

[54] Johannes Cornelius van der Linde, Elvis Fosso-Kankeu, Gerhard Gericke, Frans Waanders, Louise Dreyer, Nico Lemmer. 2019. Flocculant types and operating conditions influencing particles settling rates in feed water used at a coal power plant. Desalination and Water Treatment. 150: 293-300. https://doi.org/10.5004/dwt.2019.23735

[55] Fosso-Kankeu E., Potgieter J. and Waanders F.B. 2019. Removal of malachite green and toluidine blue dyes from aqueous solution using a clay-biochar composite of bentonite and sweet sorghum bagasse. International Journal of Applied Engineering Research. 14(6): $1324-1333$.

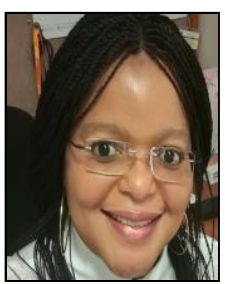

Ms. Innocentia Erdogan is currently a Lecturer at Cape Peninsula University of Technology in the Department of Chemical Engineering. Innocentia is also a $\mathrm{PhD}$ candidate at the School of Chemical and Minerals Engineering, North West University. 